\title{
Acetobacter acidum-mucosum Tosic \& Walker, n.sp., an Organism Forming a Starch-like Polysaccharide
}

\author{
BY J. TOSIC AND T. K. WALKER \\ College of Technology, University of Manchester
}

SUMMARY : A new species of Acetobacter, A. acidum-mucosum, isolated from a sample of brewery yeast is proposed. In a malt extract medium at pH 4.5 or lower it forms large capsules and a voluminous viscid sediment, whereas at $\mathrm{pH}$ values above 4.9 the capsules are smaller and the deposit is powdery. Its ability to form a starch-like polysaccharide is a characteristic which has not been noted in the case of any other species of Acetobacter.

During studies of Acetobacter species obtained from natural sources, Walker \& Tosic (1942) isolated an organism which possessed all the generic characters of Acetobacter, but which showed marked specific differences from eighteen authentic cultures of known species of this genus. This paper describes the characters of the new organism.

\section{METHODS}

The standardized procedure for characterization of Acetobacter species, described in an earlier communication (Tosic \& Walker, 1946) was employed throughout. The giant colonies shown in Pl. 1, fig. 3 were prepared by Dr Dora Kulka, by the method described by Kulka, Preston \& Walker (1949).

\section{DESCRIPTION OF THE ORGANISM}

\section{Morphological characters}

Shape, size and arrangement of cells. In standard malt extract at $30^{\circ}$, 24-48 hr. after inoculation the majority of the cells were coccoid forms while others appeared as short rods. Their dimensions varied from $0 \cdot 6 \times 0 \cdot 8 \mu$. to $0.8 \times 0.8 \mu$. In hanging-drop preparations mainly single cells were seen, but some pairs, short chains and irregular groupings were also noted. Cells taken from a malt extract agar culture after incubation at $30^{\circ}$ for $48 \mathrm{hr}$. were mostly $0.8 \times 1.1 \mu$. in size (see Pl. 1, fig. 1). Motility was not observed.

Thread and swollen cell formations. Cultures grown for $24 \mathrm{hr}$. in malt extract medium at $30^{\circ}$ were raised in temperature to $40^{\circ}$. Sixteen hours later a large number of cells appeared as long threads and after a further $36 \mathrm{hr}$. swollen forms were also seen.

Staining. Carbol fuchsin and Loeffler's methylene blue gave satisfactory results. The Gram stain was negative. Neither endospores nor flagella were detected.

Capsules were detected by Baker's technique (Baker, 1920). The size of capsules in malt extract medium varied, depending on the $\mathrm{pH}$ to which the medium was adjusted. Thus, at $\mathrm{pH} 4.5$ or below, cells approximately $0.7 \times 1.4 \mu$. 
were seen within capsules of average dimensions $3 \cdot 2 \times 4 \cdot 8 \mu$, but some capsules were very large, even up to $8 \mu$. in length. At pH 4.9 or above, the majority of the capsules measured $1.6 \times 2.0 \mu$. and enclosed cells of dimensions $0.6 \times 0.8 \mu$.

\section{Cultural characters}

Single colonies on malt extract agar plates at $25^{\circ}$. At 7 days, surface colonies were round, $1.5-2.5 \mathrm{~mm}$. in diameter, convex with entire margin, glistening, smooth and wet in appearance, opaque and of greyish yellow colour, pasty, and the cells could readily be suspended in water. At 14 days the appearance was similar, but the average size was about $3 \mathrm{~mm}$. in diameter.

Giant colony. Convex, semi-transparent, very shiny (see Pl. 1, fig. 3). For comparison there are shown on the same plate giant colonies of (I) A. suboxydans, a very delicate, opaque film, not coherent; (II) $A$. acetigenum, a dome-shaped, completely opaque and very coherent colony; (III) $A$. acetosum, raised growth (but not dome-shaped), opaque and of butyrous consistency.

Streak on malt extract agar at $30^{\circ}$. Growth visible at $24 \mathrm{hr}$. At 3 days, growth moderately strong, echinulate (lower part) and nodose, glistening, translucent with a greyish tinge. At 7 days, similar growth but becoming slightly raised and opaque. Stab in malt extract agar at $30^{\circ}$. Slight beaded growth along line of inoculation.

Streak on malt extract gelatin at $20^{\circ}$. Growth visible after $48 \mathrm{hr}$.; at 3 days, slight nodose growth; after 7 days, moderately strong, echinulate, greyish and glistening. Growth very weak in a stab culture.

Streak on nutrient broth agar at $30^{\circ}$. Growth visible after $28 \mathrm{hr}$. At 3 days, growth slight, beaded and greyish in colour. In the stab culture only slight beaded growth developed.

Streak on glucose yeast-water agar at $30^{\circ}$. Growth moderately strong and in appearance similar to that on nutrient broth-agar.

Growth in standard malt extract liquid medium, $30^{\circ}, \mathrm{pH}$ 5. Growth visible at $18 \mathrm{hr}$. At 3 days a delicate bluish ascending film had formed on the moderately turbid liquid. At 7 days turbidity was somewhat more pronounced and a scanty powdery sediment had formed. The liquid became less acid, the $\mathrm{pH}$ value rising from $5 \cdot 0$ to $6 \cdot 0$.

Growth in pasteurized beer. This type of growth was entirely different from that in malt extract. At 3 days a gelatinous, friable and greyish coloured surface cover had formed on the turbid medium. Turbidity increased and at 7 days a voluminous and viscid sediment had been deposited. The liquid was not ropy. In cultures in beer a strong odour of acetic acid and a fall of $\mathrm{pH}$ value were noted soon after growth became evident.

Nutrient broth. Growth was slower and weaker than in malt extract or in pasteurized beer. At 7 days a bluish ascending film was noted, the liquid was turbid and a scanty powdery sediment was present.

Yeast-water $(10 \%, w / v)$. Growth slight, enhanced by addition of any one of the following: ethanol, propanol, ethyleneglycol, glycerol, L-arabinose, D-xylose, D-glucose, D-fructose, maltose. Addition of lactose or of sucrose did 
not stimulate growth. In all these cases an even turbidity, a delicate bluish ascending film and a powdery sediment were produced.

Effect of $\mathrm{pH}$ value on the type of growth. This was investigated on observing the difference in type of growth in such related media as malt extract and pasteurized beer. As it was shown that neither the yeast extract and hop antiseptic present in pasteurized beer, nor the lower specific gravity of the beer as compared with malt extract medium affected the type of growth, the effect of pH value was studied. It was found that malt extract adjusted to pH 4.5 or below by addition of acetic, lactic or sulphuric acid, produced the type of growth characteristic of the beer cultures. Alternatively, the same result was attained by addition of sufficient ethanol to the medium to provide, on oxidation, that quantity of acetic acid necessary to lower the $\mathrm{pH}$ value to below 4.5. The authors have begun a study of the viscid product formed at pH values below 4.5 .

\section{Physiological characters}

Relation to temperature. In the malt extract medium the optimum range for growth was $25-30^{\circ}$. Slow growth occurred at $14^{\circ}$ and in course of time the development became as strong as that at $30^{\circ}$. Growth at $37^{\circ}$ was weaker than at $30^{\circ}$ and the organism died when the inoculated medium was incubated at $42^{\circ}$. Relation to oxygen. The organism is aerobic, but tolerates a deficiency of oxygen to a greater degree than can $A$. suboxydans; but it cannot grow at an oxygen deficiency which was tolerated in a comparative study by $A$. turbidans. Relation to hydrogen ion concentration. In malt extract, growth is strong between $\mathrm{pH} \mathrm{6.0} \mathrm{and} \mathrm{3.7.} \mathrm{Growth} \mathrm{was} \mathrm{delayed} \mathrm{at} \mathrm{pH} 7 \cdot 0$ and 3.10; no development at pH 3.0. Resistance to ethanol. Addition of $8 \mathrm{ml}$. of ethanol to $100 \mathrm{ml}$. of the malt extract delayed growth for $48 \mathrm{hr}$., and $10 \mathrm{ml}$. of ethanol increased the lag-phase of growth to 21 days.

\section{Biochemical characters}

(a) Gas formation at $30^{\circ}$. The organism did not produce gas in Durham tubes in any of the liquid media mentioned in this communication. (b) Acid formation in different media at $30^{\circ}$. Acid was produced in yeast-water cultures containing $2 \%(w / v)$ of ethanol, propanol, ethyleneglycol, $D$-xylose or D-glucose. No acid was formed when glycerol, L-arabinose, D-fructose, D-galactose, sucrose, lactose, maltose, mannitol, salicin and dextrin, respectively, in yeast-water, were employed as the medium. Acetic acid was formed on oxidation of ethanol. (c) Utilization of acetic acid. In yeast-water cultures containing $2 \%(\mathrm{w} / \mathrm{v})$ of acetic acid, the organism utilized $38 \%$ of the acid in 14 days at $30^{\circ}$. (d) Catalase reaction, positive. (e) Voges-Proskauer reaction, negative. $(f)$ Gelatin liquefaction, none. (g) Nutritional nitrogen requirement. The organism cannot utilize ammonium salts as the sole source of nitrogen.

Formation of a substance giving positive tests for starch. It was noticed that the abundant surface growth produced by the organism on malt extract agar and also the cell material of giant colonies on the same medium, gave an intense blue-black coloration when treated with Lugol's iodine-potassium iodide solu- 
Journal of General Microbiology, Vol. 4, No. 2

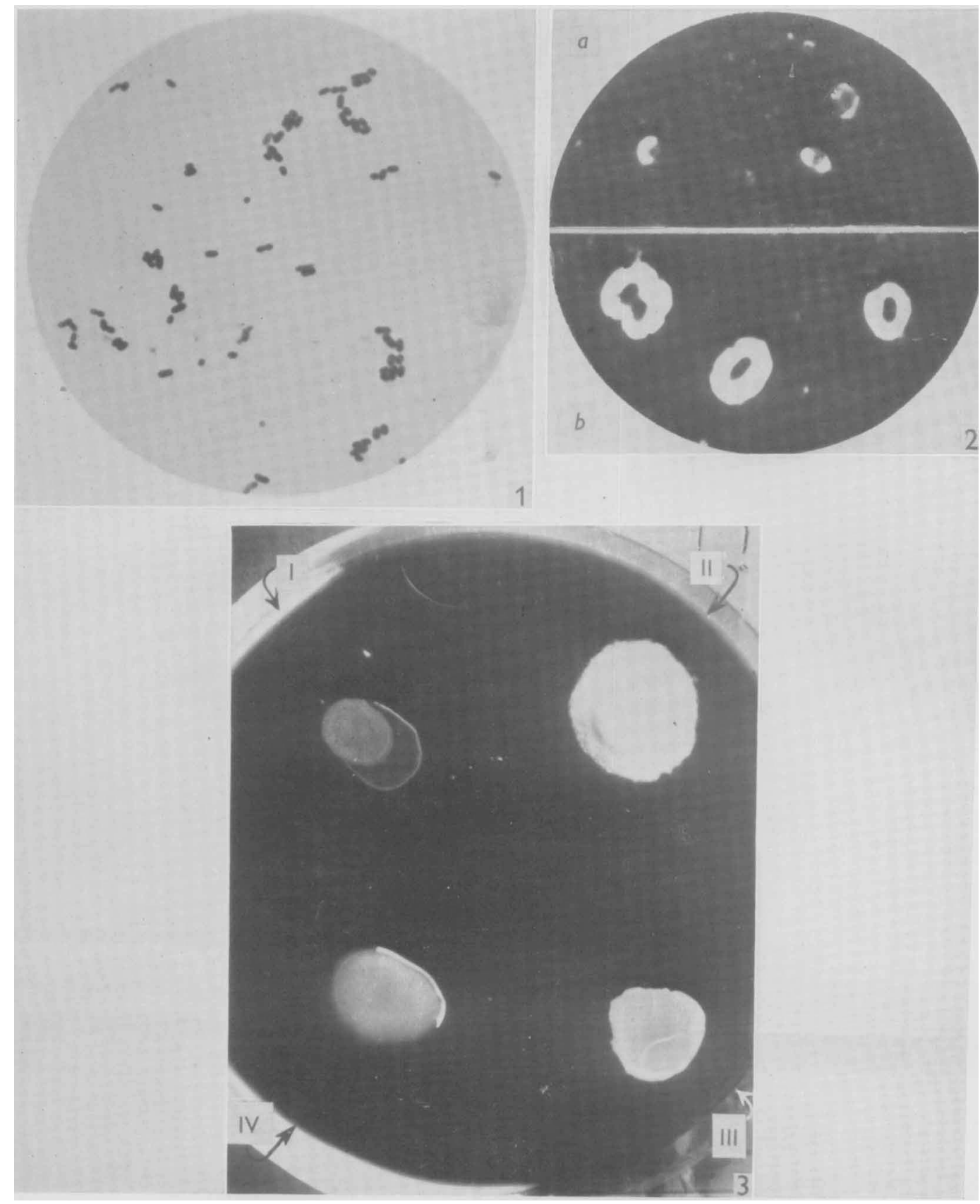

Figs. 1-3

J. Tosic \& T. K. Walker-Acetobacter acidum-mucosum N.Sp. Plate 1 


\section{REFERENCES}

BAKER, S. L. (1920). Technique for the demonstration of the capsules of bacteria. Brit. J. exop. Path. 1, 127.

Breed, R. S., Murray, E. G. D. \& Hitchens, A. P. (1948). Bergey's Manual of Determinative Bacteriology, 6th ed. London: Baillière, Tindall and Cox.

Henneberg, W. (1926). Handbuch der Garungsbakteriologie. Berlin: Parey.

Jørgensen, A. (1948): Micro-organisms and Fermentation, 7th ed. London: Griffin.

Kulka, D., Preston, J. M. \& Warker, T. K. (1949). Giant colonies of Acetobacter species as an aid to identification. J. Inst. Brew. 55, 141.

SHIMwell, J. L. (1936). Study of a new species of Acetobacter (A. capsulatum) producing ropiness in beer and beer-wort. J. Inst. Brew. 42, 585.

Tosic, J. \& Walker, T. K. (1946). Procedure for the characterisation of the acetic acid bacteria. Parts I and II. J. Soc. chem. Ind., Lond., 65, 104 and 180.

WALKER, T. K. \& Tosic, J. (1942). Acetobacter species as common contaminants of brewery yeast. Biochem. J. 36, vii.

\section{EXPLANATION OF PLATE}

Fig. 1. Cells of Acetobacter acidum-mucosum n.sp. grown on malt extract agar at $30^{\circ}$ for $48 \mathrm{hr} .(\times 1200$. $)$

Fig. 2. Cells of $A$. acidum-mucosum grown in malt extract medium at $30^{\circ}$ for 10 days, showing capsules formed $(a)$ at $\mathrm{pH} \% \cdot 0$, and $(b)$ at $\mathrm{pH} 4 \cdot 0 .(\times 2100$. $)$

Fig. 3. Giant colonies of Acetobacter spp., grown on malt extract agar at $17-21^{\circ}$ for 14 days. Photographed with top lighting $(\times 1)$. I, A. suboxydans; II, A. acetigenum; III, A. acetosum; IV, A. acidum-mucosum.

(Received 19 July 1949) 